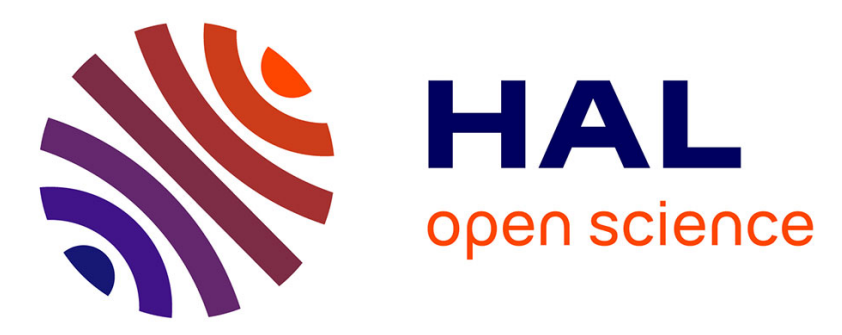

\title{
DNA strand breaks in grass shrimp embryos exposed to highway runoff sediments and sediments with coal fly ash
}

\author{
Richard F. Lee, Luis Felipe H. Niencheski, Karrie Brinkley
}

\section{To cite this version:}

Richard F. Lee, Luis Felipe H. Niencheski, Karrie Brinkley. DNA strand breaks in grass shrimp embryos exposed to highway runoff sediments and sediments with coal fly ash. Marine Environmental Research, 2008, 66 (1), pp.164. 10.1016/j.marenvres.2008.02.050 . hal-00563020

\section{HAL Id: hal-00563020 \\ https://hal.science/hal-00563020}

Submitted on 4 Feb 2011

HAL is a multi-disciplinary open access archive for the deposit and dissemination of scientific research documents, whether they are published or not. The documents may come from teaching and research institutions in France or abroad, or from public or private research centers.
L'archive ouverte pluridisciplinaire HAL, est destinée au dépôt et à la diffusion de documents scientifiques de niveau recherche, publiés ou non, émanant des établissements d'enseignement et de recherche français ou étrangers, des laboratoires publics ou privés. 


\section{Accepted Manuscript}

DNA strand breaks in grass shrimp embryos exposed to highway runoff sediments and sediments with coal fly ash

Richard F. Lee, Luis Felipe H. Niencheski, Karrie Brinkley

PII:

S0141-1136(08)00078-0

DOI:

10.1016/j.marenvres.2008.02.050

Reference:

MERE 3224

To appear in:

Marine Environmental Research

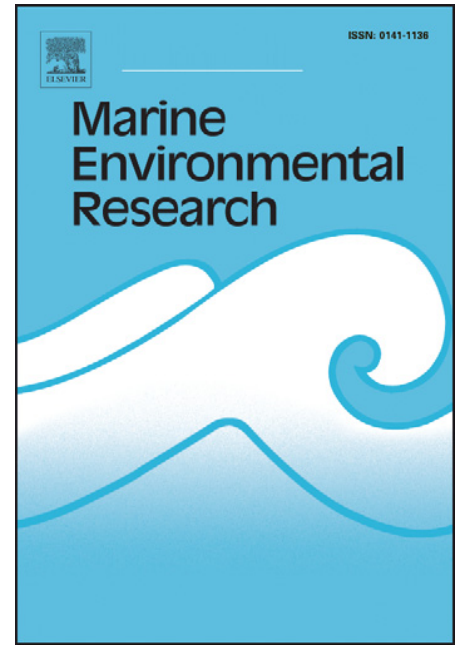

Please cite this article as: Lee, R.F., Niencheski, L.F.H., Brinkley, K., DNA strand breaks in grass shrimp embryos exposed to highway runoff sediments and sediments with coal fly ash, Marine Environmental Research (2008), doi: 10.1016/j.marenvres.2008.02.050

This is a PDF file of an unedited manuscript that has been accepted for publication. As a service to our customers we are providing this early version of the manuscript. The manuscript will undergo copyediting, typesetting, and review of the resulting proof before it is published in its final form. Please note that during the production process errors may be discovered which could affect the content, and all legal disclaimers that apply to the journal pertain. 


\title{
DNA strand breaks in grass shrimp embryos exposed to
}

\section{highway runoff sediments and sediments with coal fly ash}

\author{
Richard F. Lee ${ }^{a, *}$, Luis Felipe H. Niencheski ${ }^{\text {b }}$, Karrie Brinkley ${ }^{a}$ \\ ${ }^{a}$ Skidaway Institute of Oceanography, 10 Ocean Science Circle, Savannah, GA 31411, USA \\ ${ }^{b}$ Department of Chemistry, Fundação Universidade Federal do Rio Grande, Brazil
}

\begin{abstract}
Embryo production was reduced in female grass shrimp exposed to sediments with added coal fly ash and to sediments collected from an estuarine station containing high PAH concentrations due to its proximity to a highway storm drain. Grass shrimp embryos exposed to pore water from the high PAH and high metal sediments showed both reduced hatching and increases in DNA strand breaks (comet assay). Sediments with added coal fly ash had high concentrations of vanadium and selenium which may have contributed to effects similar to those observed with sediments with high PAH. The embryo pore water bioassay (hatching/ DNA strand breaks) gave results comparable to those observed for reproduction effects (reduced embryo production/embryo hatching) with female grass shrimp exposed to whole sediment.
\end{abstract}


Keywords: DNA strand breaks; Comet assay; Toxicity; Coal ash; Sediments; Embryo

*Corresponding author. Tel.: +1 912 5982494; fax: +1 9125982310

E-mail address: dick.lee@ skio.usg.edu (R.F. Lee)

Grass shrimp are an important component of the estuarine food web in the southeast United States. Grass shrimp embryos, enclosed in egg sacs, go through 10 stages while attached to the female pleopods. After stage 10 a free swimming zoea emerges from the egg sac. Several DNA lesions (e.g. strand breaks, modified bases, DNA-DNA crosslinks, DNA-protein crosslinks) are produced after exposure to genotoxicants, e.g. metals and PAHs. Reduced embryo production observed when grass shrimp are exposed to metals and PAHs (Lee et al., 2004) may be linked to damaged DNA. In the present study comparisons were made between reproduction processes in grass shrimp exposed to sediments containing coal combustion residues or highway runoff and hatching rates/ DNA strand breaks (comet assay) in embryos exposed to pore water from these sediments.

Sediments were collected from three stations in an estuary in Hilton Head, South Carolina (USA): station A - next to a highway storm drain; station B -100 m away from the drain; station $\mathrm{C}-500 \mathrm{~m}$ away from the drain. For coal fly ash exposure experiments, $400 \mathrm{~g}$ of coal fly ash from power plants in Augusta, GA (USA) or from Candiota, Rio Grande do Sul (Brazil) was blended with $2000 \mathrm{~g}$ of reference sediment. Coal ash is one of the residues from coal combustion and is composed primarily of metal oxides. Reference 
sediment was from the Skidaway River estuary (Savannah, GA) (USA). Pore water was collected by centrifugation of sediments at $1000 \mathrm{X} \mathrm{g}$ for $30 \mathrm{~min}$. Sediments to be analyzed for PAHs in sediment were freeze dried, extracted with methylene chloride and extracts passed through a silica gel column. The PAH fractions from the silica gel column were analyzed with a Hewlett Packard 6890 Series Plus Gas Chromatography coupled to a 5973 mass spectrometer. Twenty three individual PAH analytes were quantified with a detection limit of $10 \mathrm{ng} / \mathrm{g}$ for each analyte. Metals (V, Cr, Mn, Ni, Cu, Zn, As, Se, Ag, $\mathrm{Cd}, \mathrm{Pb}$ ) in sediment pore water samples were determined by ICP-MS (Fison Plasma Quad II Plus) equipped with a nebulizer. To determine reproductive parameters, 20 juvenile grass shrimp were added to aquaria contain $700 \mathrm{~g}$ of test sediment and 401 of seawater. Three aquaria were used for each station or experiment $(n=3)$. Salinity of the water was $28 \mathrm{ppt}$ and temperature was maintained at $27^{\circ} \mathrm{C}$. Shrimp were fed Artemia and kept under $12 \mathrm{~h}$ light/12 h dark regime. Every 5 days the following parameters were determined: (a) mortality; (b) number of females with mature ovaries; (c) number of females with attached embryos. Grass shrimp were exposed to test sediments for 60 days with no change of seawater. Embryo hatching rates were determined after transferring 25 stage 8 embryos to polystyrene plates with each well containing $1.2 \mathrm{ml}$ of estuarine water and 1 embryo. For pore water bioassays, $0.1 \mathrm{ml}$ of sediment pore water was added to $1.1 \mathrm{ml}$ of filtered estuarine water in a polystyrene plate with each well containing one stage 8 embryo (25 embryos per test) and hatching rates determined. For assessment of DNA strand breaks, the comet assay was carried out on stage 7 embryos exposed to sediment pore water (diluted 1:10 with filtered estuarine water) for $24 \mathrm{~h}$. The comet assay followed the procedures described by Singh et al., (1988) with modifications described 
by Lee and Kim (2002). A computerized image-analysis system (Komet Version 4.01, Kinetic Imaging Ltd.) was used to determine \% DNA in tail of fifty randomly selected cells per slide.

At different distances from the highway storm drain, total PAH concentrations (sum of 24 analytes) were $29,1.5$ and $0.1 \mu \mathrm{g} / \mathrm{g}$ sediment for stations $\mathrm{A}, \mathrm{B}$, and C, respectively (Table 1). Concentrations of the different PAH analytes in these stations were previously reported (Lee et al., 2004). In the coal fly ash experiment, the concentrations of vanadium and selenium in sediment pore water are reported (Table 1) since the concentrations of these metals in coal fly ash sediment pore water (V: 129-278 $\mu \mathrm{g} / \mathrm{l}$; Se: $115-256 \mu \mathrm{g} / \mathrm{l})$ was much higher than their concentrations in reference sediment pore water (V: 1-2 $\mu \mathrm{g} / \mathrm{l}$; Se: $0.04-0.1 \mu \mathrm{g} / \mathrm{l})$. High selenium concentrations were found in sediment pore water near a coal-fired power station (Jung and Batley, 2004). Grass shrimp exposed to coal combustion resides has increased DNA strand breaks and had accumulated selenium (Kuzmick et al., 2007). Embryos exposed to pore water from sediment close to a highway storm drain (station A) showed significant $(\mathrm{p}<0.05)$ difference with respect DNA strand breaks (38\% DNA in tail) and reduction in embryo hatching $(35 \%)$ when compared with embryos exposed to sediments distant from the storm drain (Stations B and C) (Table 1). Embryos exposed to sediment with coal fly ash had reduced hatching (25-35\%) and increased DNA strand breaks (38-41\% DNA in tail) compared to controls. Zoea that emerged died within a few hours. Female grass shrimp exposed to highway runoff sediment and coal fly ash sediment, showed significant reduction in embryo production and embryo hatching (Table 2) compared to females exposed to reference sediment. 


\section{References}

Jung, R.F., and Batley, G.E. (2004). Marine Pollution Bulletin, 49, 295-298.

Kuzmick, D.M., Mitchelmore, C.L., Hopkins, W.A., and Rowe, C.L. (2007). Science of the Total Environment, 373, 420-430.

Lee, R., and Kim, G.B. (2002). Marine Environmental Research, 54, 465-469.

Lee, R.F., Maruya, K.A., and Bulski, K. (2004). Marine Environmental Research, 58, 713-717.

Singh, N.P., McCoy, M.T., Tice, R.R., and Schneider, E.L. (1986). Experimental Cell Research, 175, 184-191. 
Table 1

Bioassays with grass shrimp embryos exposed to sediment pore water from reference station, highway runoff stations and sediment with added coal fly ash

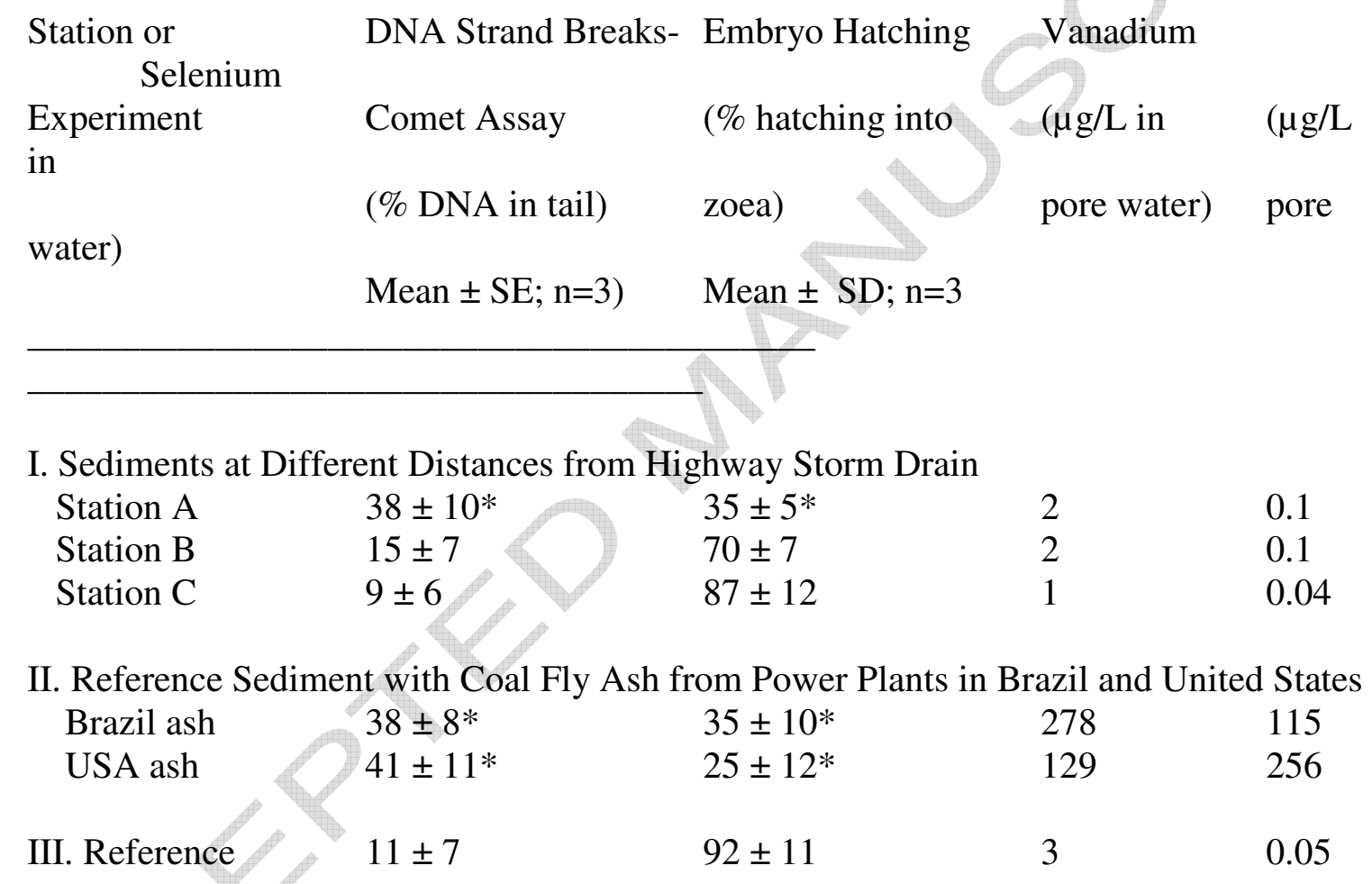

*Denotes significant difference from reference sediment at $\mathrm{P}<0.05$ (ANOVA, F-test) 
Table 2.

Reproduction parameters in female grass shrimp exposed to sediments from highway runoff stations or sediments with coal fly ash

$\begin{array}{llll}\begin{array}{l}\text { Station or } \\ \text { Experiment }\end{array} & \begin{array}{l}\text { Embryo production } \\ \text { by gravid females } \\ (\% \text { gravid females } \\ \text { producing embryos })\end{array} & \begin{array}{l}\text { Embryo hatching } \\ (\% \text { hatching into } \\ \text { Mean } \pm \text { SD }(\mathrm{n}=3)\end{array} & \begin{array}{l}\text { Total PAHs } \\ \text { of sediment } \\ \text { Mean } \pm \text { SD }(\mathrm{n}=3)\end{array} \\ & & & \\ & & \end{array}$

Sediments at different distances(in parenthesis) from highway storm drain

$\begin{array}{lllr}\text { Station A }(0 \mathrm{~m}) & 42 \pm 11^{*} & 35 \pm 5^{*} & 28.8 \\ \text { Station B }(100 \mathrm{~m}) & 53 \pm 6 & 46 \pm 13^{*} & 12.3 \\ \text { Station C }(500 \mathrm{~m}) & 65 \pm 12 & 85 \pm 6 & 1.0\end{array}$

Coal fly ash from power plants in Brazil and United States added to reference sediments ${ }^{\mathrm{a}}$
Brazil ash
$52 \pm 7 *$
$24 \pm 8 *$
3.4
USA ash
$30 \pm 12 *$
$7 \pm 8 *$
2.9

Reference sediment

$71 \pm 14$

$88 \pm 4$

1.5

${ }^{\mathrm{a}} 400 \mathrm{~g}$ of coal ash added to $2000 \mathrm{~g}$ of reference sediment

*Denotes significant difference from reference sediment at $\mathrm{P}<0.05$ (ANOVA, F-test) 